\title{
ANALISIS IMPLEMENTASI PELAYANAN PDAM UNIT BOLIYOHUTO KABUPATEN GORONTALO
}

\author{
Agus Pariono ${ }^{1}$, Andi Yusuf Katili², Mohammad Imran ${ }^{3}$ \\ ${ }^{12}$ STIA Bina Taruna Gorontalo, ${ }^{3}$ STITEK Bina Taruna Gorontalo \\ guspri811@gmail.com ${ }^{1}$, yusuf2801@gmail.com ${ }^{2}$, imransains02ars@gmail.com ${ }^{3}$
}

\begin{abstract}
ABSTRAK
Penelitian ini bertujuan untuk mendeskripsikan dan menganalisis implementasi pelayanan Perusahaan Daerah Air Minum Unit Boliyohuto Kabupaten Gorontalo serta untuk mengetahui faktor pendukung dan penghambat dalam pelaksanaan pelayanan publik Perusahaan Daerah Air Minum Unit Boliyohuto Kabupaten Gorontalo. Dalam penelitian ini yang menjadi fokus masalah meliputi implementasi tentang pelayanan publik PDAM Unit Boliyohuto Kabupaten Gorontalo yaitu: (1). Komunikasi, (2). Sumber daya, (3). Disposisi, (4). Struktur birokrasi. Metode adalah penelitian deskriptif dengan pendekatan kualitatif. Hasil penelitian ini menunjukkan bahwa Implementasi pelayanan Perusahaan Daerah Air Minum Unit Boliyohuto Kabupaten Gorontalo, belum maksimal. Sumberdaya manusia masih kurang menjadi kendala dalam pelayanan, fasilitas pendukung pelayanan yang belum memadai, serta pelayanan yang diberikan pegawai masih sangat lambat dikarenakan kurangnya jumlah pegawai dalam melayani, serta beberapa faktor pendukung dalam pelayanan PDAM Unit Boliyohuto Kabupaten Gorontalo antara lain adalah sumber air yang masih melebihi kapasitas, kekompakan staf menjadikan kekuatan dalam menyelesaikan permasalahan mengenai pelayanan. Sedangkan faktor penghambat antara lain adalah kurangnya fasilitas dan jumlah pegawai yang ada sehingga menyebabkan lambat dalam melayanani serta jarak tempuh instalansi yang medannya sulit dilalui, dan beberapa pelanggan yang masih membayar door to door karena belum memadai mengenai jaringan.
\end{abstract}

Kata Kunci: Implementasi, Pelayanan Publik, PDAM Unit Boliyohuto

\begin{abstract}
This study aims to describe and analyze the implementation of the services of the Regional Drinking Water Company, Boliyohuto Unit, Gorontalo Regency and to determine the supporting and inhibiting factors in the implementation of public services for the Regional Water Company, Boliyohuto Unit, Gorontalo Regency. In this study, the focus of the problem includes the implementation of public services for PDAM Boliyohuto Unit, Gorontalo Regency, namely: (1). Communication, (2). Resources, (3). Disposition, (4). Bureaucratic structure. The method is a descriptive research with a qualitative approach. The results of this study indicate that the service implementation of the Regional Water Company, Boliyohuto Unit, Gorontalo Regency, has not been maximized. Human resources are still not an obstacle in service, service support facilities are not adequate, and the services provided by employees are still very slow due to the lack of employees in serving, as well as several supporting factors in the service of PDAM Boliyohuto Unit, Gorontalo Regency, among others, water sources that still exceed
\end{abstract}


capacity, the cohesiveness of the staff makes it a strength in solving problems regarding services. While the inhibiting factors include the lack of facilities and the number of existing employees, causing slow service and installation distances that are difficult to pass through, and some customers who still pay door to door because they are inadequate regarding the network.

Keywords: Implementation, Public Service, PDAM Unit Boliyohuto

\section{PENDAHULUAN}

Pelayanan publik merupakan tanggungjawab pemerintah dan dilaksanakan oleh instansi pemerintah, baik itu di pusat, di daerah, dan di lingkungan Badan Usaha Milik Negara. Pelayanan Publik dapat diartikan sebagai pemberian layanan (melayani) keperluan orang atau masyarakat yang mempunyai kepentingan pada organisasi tersebut sesuai dengan aturan pokok dan tata cara yang telah ditetapkan (Hamid, 2015). Perusahaan Daerah Air Minum (PDAM) merupakan perusahaan yang dikelola oleh pemerintah daerah yang dalam pengoperasiannya perlu mengutamakan pemenuhan kepuasan masyarakat melalui penyediaan air bersih. Untuk itu pelayanan yang diberikan seharusnya memenuhi standar kualitas pelayanan yang baik, atau berkualitas dengan harga yang terjangkau, hal ini juga dijelaskan dalam penelitian (Riyanto, 2018).

Guna mewujudkan peningkatan implementasi pelayanan itu maka harus terjadi pergeseran pemikiran dari para birokrat khususnya dalam hal pemberian pelayanan pada publik. Kinerja birokrasi publik harus diarahkan pada bagaimana menciptakan dan memberikan pelayanan yang baik dan memuaskan bagi publik. Kepuasan masyarakat menjadi tolok ukur yang nyata atas kinerja birokrasi publik. Namun, sampai saat ini usaha pemerintah dalam memenuhi kebutuhan masyarakat mengenai PDAM masih belum dapat memenuhi harapan masyarakat. Banyak anggota masyarakat yang mengeluh dan merasa tidak puas dengan pelayanan yang diberikan oleh PDAM milik pemerintah ini baik itu dari segi pelayanan yang kurang diperhatikan oleh petugas, lama waktu pelayanan, keterampilan petugas, sarana/fasilitas, serta waktu tunggu untuk mendapatkan pelayanan.

PDAM Unit Boliyohuto Kabupaten Gorontalo adalah satu satunya PDAM di Boliyohuto Group. Untuk mencapai derajat pelayanan yang optimal dan memuaskan bagi pelanggan melalui upaya peningkatan kualitas, perlu adanya pelayanan yang baik yang diberikan oleh pegawai oleh sebab itu dituntut kinerja yang tinggi dari pegawai. Pelayanan pada PDAM Unit Boliyohuto Kabupaten Gorontalo masih belum sesuai dengan keinginan masyarakat karena masih seringnya terdengar keluhan pelanggan dimana masih seringnya pegawai PDAM yang lambat dalam memberikan pelayanan, kepada pelanggan sering menunggu lama untuk mendapatkan giliran dilayanani oleh pegawai. 
Demikian halnya PDAM Unit Boliyohuto Kabupaten Gorontalo tempat penelitian, dalam perjalanannya sering mendapatkan keluhan dari pelanggan (masyarakat) dikarenakan buruknya pelayanan yang diberikan seperti: air kadang mati dan kotor, pipa mengalami kebocoran, alat meter kadang mati, dari beberapa masalah yang ada, masalah pelayanan yang sering dikeluhan oleh masyarakat, dimana kinerja pegawai dalam memberikan pelayanan dalam hal ini ketepatan waktu dalam memberikan pelayanan, kuantitas dan kualitas pelayanan yang masih sangat lambat. Lambat kinerja pelayanan akan membangun citra buruk pada Perusahaan daerah air minum (PDAM) tersebut, dimana pelanggan yang merasa tidak puas akan menceritakan kepada rekanrekannya. Begitu juga sebaliknya, semakin tinggi kinerja pelayanan yang diberikan akan menjadi nilai plus bagi PDAM, dalam hal ini pelanggan akan merasa puas terhadap pelayanan yang diberikan oleh PDAM. Perusahaan Daerah Air Minum dapat mengetahui kinerja pelayanan dari para pelanggan melalui umpan balik yang diberikan pelanggan kepada PDAM tersebut, sehingga dapat menjadi masukan untuk peningkatan kinerja pelayanan. Sebab itu dituntut kinerja yang tinggi dari pegawai pelayanan di PDAM Unit BoliyohutoKabupaten Gorontalo disebabkan masih belum sesuai dengan keinginan masyarakat karena masih sering terdengar keluhan pelanggan dimana masih sering pegawai PDAM yang lambat dalam memberikan pelayanan.

Dari uraian di atas $\begin{array}{r}\text { dapat } \\ \text { dikemukakan, bahwa }\end{array}$
kurang terpenuhinya hak-hak masyarakat untuk mendapatkan pelayanan yang baik dari pegawai perusahaan daerah air minum. Serta belum maksimalnya pegawai PDAM dalam mengimplementasikan tentang pelayanan publik. Oleh karena itu implementasi pelayanan publik harus dibenahi dari sistem pelayanannya, agar mewujudkan suatu kondisi pelayanan publik yang baik.

Dengan melakukan analisa tersebut, maka akan diperoleh indikator implementasi pelayanan publik meliputi: komunikasi, sumber daya, disposisi, struktur birokrasi sebagai indikator yang diteliti dalam penelitian ini.

\section{TINJAUAN LITERATUR}

\section{Konsep Implementasi Kebijakan Publik}

Implementasi kebijakan publik merupakan tahapan yang paling krusial dalam proses kebijakan publik. Suatu program kebijakan harus diimplementasikan agar mempunyai dampak dan tujuan yang diinginkan untuk memahami implementasi kebijakan publik, hal ini dijelaskan juga oleh (Effendi, 2014).

Implementasi kebijakan dalam arti luas merupakan tahap dari proses kebijakan setelah penetapan undang- 
undang. Dimana sebagai aktor, organisasi, prosedur dan teknik kerja sama untuk menjalankan kebijakan dalam upaya untuk meraih tujuan kebijakan atau program. Implementasi dilihat dari segi lainya adalah suatu fenomena yang kompleks yang mungkin dapat dipahami sebagai suatu proses, suatu keluaran (output), maupun sebagai suatu dampak (outcome). Menurut (Katili \& Tueno, 2020) "suatu peraturan akan dibahas, disetujui dan diterbitkan berupa peraturan disebabkan adanya suatu masalah, yang memuat berbagai tindakan dan sanksi agar dipatuhi oleh sasaran atau target peraturan tersebut".

Dalam konteks kebijakan suatu produk diimplementasikan dan konseptualisasikan sebagai suatu proses atau serangkaian keputusan dan tindakan yang ditunjukkan agar keputusankeputusan dapat diterima oleh lembaga legislatif bisa dijalankan, implementasi juga bisa diartikan dalam konteks keluaran, atau sejauh mana tujuan yang telah direncanakan mendapat dukungan.

\section{Model Implementasi Kebijakan}

Perumusan suatu kebijakan akan lebih mudah apabila menggunakan suatu model atau pendekatan tertentu, jika permasalahan kebijakan tersebut semakin kompleks dan semakin mendesak suatu pemecahan masalah. Oleh karena itu diperlukan model, teori atau pendekatan yang relatif operasional yang mampu menjelaskan hubungan kausalitas antar variabel yang menjadi fokus permasalahan.
Model kebijakan meskipun berguna dan perlu, juga merupakan hasil ciptaan yang sifatnya tidak dapat dipercaya. Dengan menyederhanakan situasi problematik, model secara tak terelakkan menimbulkan distorsi yang selektif terhadap realitas. Model itu sendiri tidak dapat menjelaskan bagaimana memisahkan persoalan-persoalan yang esensial dan tidak esensial, juga tidak menjelaskan, meramalkan, mengevaluasi atau menyarankan, karena pertimbanganpertimbangan tersebut berada di luar model dan tidak merupakan bagian darinya. Karena model dapat membantu kita mengatasi tugas, kuncinya bukan model yang memberikan asumsi untuk menginterprestasikan realitas yang dijelaskan model. Akhirnya, model kebijakan seringkali dikomunikasikan dengan pengambilan keputusan dan pelaku-pelaku lain kepada siapa model tersebut dirancang sebagai pembantu kearah pengambilan keputusan yang lebih baik.

Edward III dalam (Ramdhani, 2016) mengajukan empat faktor atau variable yang berpengaruh terhadap keberhasilan atau kegagalan implementasi kebijakan. Empat variable atau faktor antara lain meliputi: komunikasi, sumberdaya, disposisi dan kemudian struktur birokrasi. Keempat variabel tersebut juga saling berhubungan satu sama lain.

\section{Pelayanan Publik}

Pelayanan adalah kunci keberhasilan dalam berbagai usaha pada kegiatan yang sifatnya jasa, baik yang 
dilakukan organisasi swasta maupun organisasi pemerintah. Secara umum pelayanan merupakan segala sesuatu yang dilakukan dalam rangka memberikan manfaat bagi orang lain atau pelayanan adalah serangkaian aktivitas untuk melakukan sesuatu yang baik bagi orang lain, baik yang berwujud maupun yang tidak berwujud yang dilakukan oleh organisasi., hal senada dijelaskan juga oleh (Budiaman, 2018); (Rezha, 2013); dan (Mouw, 2013). Sedangkan publik adalah segala sesuatu yang menyangkut kepentingan umum, jadi pelayanan publik adalah pemberian layanan (melayani) keperluan orang atau masyarakat yang mempunyai kepentingan pada organisasi itu sesuai dengan aturan pokok dan tata cara yang telah ditetapkan sehingga proses pemberian layanan dapat berjalan sesuai dengan harapan masyarakat dan tujuan organisasi (Sadhana, 2015).

Pelayanan publik (public services) oleh birokrasi publik tadi merupakan salah satu perwujudan dari fungsi aparatur negara sebagai abdi masyarakat di samping sebagai abdi negara. Pelayanan publik (public services) oleh birokrasi publik dimaksudkan untuk mensejahterakan masyarakat (warga negara) dari suatu negara kesejahteraan (welfare state). Pelayanan umum menurut (Lembaga Administrasi Negara Republik Indonesia, 2018) diartikan sebagai segala bentuk kegiatan pelayanan umum yang dilaksanakan oleh Instansi Pemerintah di Pusat, di daerah dan di lingkungan Badan Usaha Milik Negara / Daerah dalam bentuk barang dan atau jasa baik dalam rangka upaya kebutuhan masyarakat maupun dalam rangka pelaksanaan ketentuan peraturan perundang-undangan. Pelayanan yang diberikan haruslah beretika sehingga pihak yang dilayani merasa puas dan terbantukan (Widodo, 2001).

\section{PERMASALAHAN}

Berdasarkan latar belakang di atas, maka dirumuskan masalah sebagai berikut: (1) Bagaimanakah Pelayanan Perusahaan Daerah Air Minum Unit Boliyohuto Kabupaten Gorontalo?; (2) Faktor-faktor apa yang menjadi pendukung dan penghambat pelayanan Perusahaan Daerah Air Minum Unit Boliyohuto Kabupaten Gorontalo?

\section{Fokus Penelitian}

Dalam penelitian ini yang menjadi fokus penelitian adalah

1. Implementasi pelayanan, yaitu: (1)

Komunikasi; (2) Sumberdaya; (3)

Disposisi; (4) Struktur birokrasi

2. Faktor-faktor penghambat dan pendukung implementasi pelayanan Perusahaan Daerah Air Minum (PDAM) Unit Boliyohuto Kabupaten Gorontalo

\section{METODE PENELITIAN}

\section{Metode Pengumpulan Data}

Untuk memperoleh informasi dan data yang akan diolah dalam penelitian ini, maka Pengumpulan data dilakukan dengan 2 cara, yaitu (1) Penelitian 
kepustakaan, dan (2) Penelitian lapangan terdiri dari: Observasi, Wawancara, dan Telaah dokumen,

\section{Analisis Data}

Dalam penelitian ini, penulis menggunakan teknik analisa data (model interaktif) yang berifat deskriptif, dimana suatu jenis penelitian yang memberikan gambaran atau uraian atas fakta-fakta berdasarkan data yang terkumpul di lapangan yang berkaitan erat dengan objek penelitian, kemudian data tersebut dipadukan dan dianalisa secara kualitatif dengan memberikan gambaran-gambaran, interpretasi atau penafsiran atau faktafakta tersebut, model interaktif, (Moleong, 2018).

Data yang telah dikumpulkan selanjutnya diananlisa melalui tahapan sebagai berikut: (1) Pengumpulan Data; (2) Reduksi data; (3) Penyajian data; dan (4) Penarikan kesimpulan

\section{HASIL PENELITIAN DAN PEMBAHASAN}

Perusahaan Daerah Air Minum (PDAM) Unit Boliyohuto Kabupaten Gorontalo sebagai jasa pelayanan air bersih sangat didambakan masyarakat. Masyarakat yang semakin kritis terhadap PDAM perlu diantisipasi dengan memberikan pelayanan yang sesuai dengan tuntutan masyarakat yaitu mendapatkan pelayanan yang mudah, cepat dan sesuai keinginan masyarakat (pelanggan), untuk itu PDAM Unit Boliyohuto Kabupaten Gorontalo terus berupaya menuju pelayanan yang lebih baik. Hasil penelitian tentang Analisis Implementasi pelayanan Perusahaan Daerah Air Minum (PDAM) Unit Boliyohuto Kabupaten Gorontalo dan faktor-faktor yang pendukung dan penghambat implementai kebijakan, dimaksudkan bahwa dalam memaksimalkan kebijakan pelayanan publik harus menjalankan substansi dari kebijakan pelayanan publik. Dalam setiap kebijakan pasti memiliki maksud dan tujuan dalam memaksimalkan kebijakan tersebut dalam pelaksanaannya.

\section{Implementasi Pelayanan Publik PDAM} Unit Boliyohuto

Teori yang digunakan peneliti dalam menilai keberhasilan suatu implementasi kebijakandapat peneliti jelaskan secara mendalam hasil dari penelitian ke dalam empat indikator yang disebutkan dalam teori Edward III meliputi komunikasi, sumber daya disposisi atau perilaku, dan struktur birokrasi. Keempat faktor inilah yang diharapkan mampu menggambarkan dengan jelas bagaimana pelaksanaan Pelayanan PDAM Unit Boliyohuto Kabupaten Gorontalo sebagai bagian dari implementasi kebijakan dalam pelayanan publik serta faktor penghambat dan pendukung pelayanan PDAM Unit Boliyohuto Kabupaten Gorontalo. Realita yang terjadi dilapangan tersebut dipengaruhi oleh fator penghambat dan pendukung implementasi kebijakan tersebut. 


\section{Komunikasi}

Komunikasi merupakan proses kegiatan atau hubungan seseorang baik melalui hubungan langsung maupun lambang-lambang, agar orang lain mengerti maksud dan tujuan tertentu. Komunikasi adalah instrumen kebijakan yang berfungsi untuk mengalirkan perintah-perintah dan arahan dari sumber pembuat kebijakan atau keputusan kepada mereka yang diberi tanggungjawab untuk melaksanakannya.

Salah satu unsur yang dapat mempengaruhi keberhasilan pelaksanaan sebuah kebijakan menurut Edward III adalah komunikasi. Komunikasi dalam konteks penelitian ini digunakan agar pelaksanaan kebijakan pelayanan ini dapat berjalan dengan baik. Hal senada dijelaskan jug aoleh (Zahara, 2018). Komunikasi ini dilakukan oleh pihak Pegawai PDAM untuk melakukan sosialisasi kepada Masarakat tentang adanya peraturan mengenai pelayanan seperti mengenai pembayaran tagihan air, sehingga masyarakat/pelanggan dapat berkomunikasi langsung dengan pegawai PDAM.

Komunikasi dalam implementasi pelayanan amat ditentukan dari beberapa unsur yang terdapat dalam komunikasi, seperti penyampaian pesan, isi pesan, media yang digunakan, serta sasaran penerima pesan. Mengenai bagaimana dimensi komunikasi yang terjadi di Kantor PDAM Unit Boliyohuto Kabupaten Gorontalo.
Penyampaian informasi merupakan faktor utama dalam hal komunikasi pelaksana kebijakan. Menurut Edward III dalam(Mulawarman \& Rosilawati, 2014), penyaluran komunikasi yang baik akan dapat menghasilkan suatu implementasi yang baik pula. Komunikasi dalam implementasi kebijakan pelayanan PDAM pada masyarakat/pelangan berupa penyampaian atau pengiriman informasi dari pegawai ke pelangan melalui sosialisasi.

Sosialisasi atau proses penyampaian informasi dilakukan oleh pihak pegawai kepada sasaran kebijakan berjalan dengan baik dan dilaksanakannya kegiatan sosialisasi adalah untuk memberikan penjelasan mengenai isi kebijakan, tujuan serta manfaat kebijakan, agar masyarakat khususnya pelanggan dapat mengerti bahwa pembayaran dapat dilaksanakan melalui online serta diberbagai tempat yang telah bekerjasama dengan PDAM, namun yang menjadi permasalahan sebagian pelangan masih dilakukan secara manual dikarenakan tidak adanya jaringan. Pelaksanaan sosialisasi dengan carabertatap muka langsung antara pegawai dengan masyarakat yang bersangkutan, dan untuk pelaksanaan sosialisasi tidak langsung yaitu dengan menggunakan brosur yang dibagikan kepada masyarakat khususnya pelanggan sehingga jelas mengenai informasi yang disampaikan.

\section{Sumberdaya \\ Sumber daya memiliki peranan penting dalam implementasi kebijakan.}


Edward III dalam (Indah \& Hariyanti, 2018)mengemukakan bahwa sumber daya merupakan faktor yang penting dalam melaksanakan kebijakan publik. Implementasi mungkin diteruskan secara cermat, jelas dan konsisten, tetapi jika para pelaksana kekurangan sumber daya yang diperlukan untuk melaksanakan kebijakan kebijakan, maka implementasi ini pun cenderung tidak efektif. Sumber Daya yang dimaksud ialah meliputi sumber daya manusia (ketersediaan staf) dan sumber daya sarana prasarana (fasilitas) yang dapat mendukung proses implementasi pelayanan publik.

\section{A. Sumber Daya Manusia}

Dalam kebijakan pelayanan PDAM

Unit Boliyohuto Kabupaten Gorontalo, sumber daya manusia belum memadai dalam menjalankan proses-proses yang seharusnya dilaksanakan untuk menyampaikan isi kebijakan pelayanan. Kekurangan sumber daya manusia menjadi kendala dalam upaya meningkatkan kualitas pelayanan kepada kelompok sasaran, dimana terlihat bahwa kekurangan sumber daya manusia dalam melaksanakan tugas dan fungsinya masih belum optimal, dikarenakan satu pegawai bekerja lebih dari satu pekerjaan, namun kurangnya sumber daya manusia tidak menjadi penghalang atau penghambat bagi pegawai justru menjadikan motivasi dan semangat kerja pada para pegawai dalam menyelesaikan tugasnya dalam hal pelayanan walaupun sering terjadi keterlambatan dalam penyelesaian pekerjaan yang ada. Sumber daya manusia adalah faktor penting dalam implementasi kebijakan pelayanan apabila sumber daya manusia cukup maka pelayanan yang diberikan akan efektif dan efesien.

\section{B. Sumber Daya Peralatan Sarana Prasarana (Fasilitas)}

Komponen ini berkaitan dengan sumber daya sarana dan prasarana pelayanan yang dimiliki. Sarana dan prasarananlah pendukung yang penting dalam sebuah unit pelayanan.Sarana dan prasarana menjadi bermanfaat jika lengkap sehingga memudahkan dalam pelayanan. Perintah-perintah implementasi mungkin berjalan dengan baik dan cermat, jelas dan konsisten,tetapi apa bila kekurangan sumber daya sarana prasarana (fasilitas) yang ada, untuk melaksanakan pelayanan, maka implementasi tidak akan berjalanan dengan baik dan efektif, serta lambat dalam pelayanan.

Kantor PDAM Unit Boliyohuto Kabupaten Gorontalo yang menunjukan bahwa fasilitas pelayanan memang masih minim sehinga mengghambat pemberian layanan dalam menyelesaikan tugasnya. Kurangnya fasilitas sanggat berpengaruh terhadap berjalannya pelayanan PDAM, dimana PDAM tidak memiliki kantor pelayanan yang memadai serta ruang pelayanan dan tunggu yang lengkap dan nyaman,serta alat-alat yang masih minim dan apa adanya serta,belum adanya sumur bor guna mengatasi berbagai permasalahan yang terjadi dari pusat sungai Tamaila yang dijadikan sumber 
penyaluran air ke pelangan, namun pegawai dalam memberikan pelayanan dengan fasilitas yang minim dan apa adanya pegawai tetap bersemangat dan berusaha meningkatkan optimalitas kinerjanya dalam memberikan layanan. Hal itu terlihat dalam kinerja petugas dalam memberikan selalu sesuai dengan peraturan dan prosedur walau kekurangan sarana dan prasarana yang ada. Ditinjau dari tingkat fasilitas yang ada pegawai dalam melaksanakan tugasnya sudah cukup baik namun yang menjadi lambatnya pelayanan adalah minimnya fasilitas yang ada dan kurangnya pegawai yang melayani sehingga pelayanan yang ada sangat lambat.

\section{Disposisi (Sikap)}

Disposisi adalah aspek yang berkaitan dengan bagaimana sikap dan dukungan para pelaksana terhadap program atau kebijakan (Ramdhani, 2016). Sikap dan dukungan sangat penting dalam proses implementasi, karena kesamaan pandangan terhadap apa yang dikerjakan bersama akan mempermudah pencapaian tujuan. Bila para pelaksana atau implementor kebijakan terpecah belah dalam hal sikap dan dukungan tersebut maka apa yang akan dicapai dari suatu kebijakan tidak akan tercapai secara efektif dan efisien, karena akan menghadapai banyak rintangan dan kendala dari aparat pelaksana kebijakan itu sendiri, dimana pelaksanaan program atau kebijakan kadangkala bermasalah apabila pelaksana yang terkait didalamnya tidak dapat menjalankan program atau kebijakan dengan baik. Apabila pelaksana memiliki disposisi yang baik, maka dia akan melaksanakan program atau kebijakan dengan baik seperti yang diinginkan oleh pembuat kebijakan, sedangkan apabila pelaksana memiliki sikap yang berbeda dengan pembuat kebijakan, maka proses pelaksanaan suatu program atau kebijakan juga tidak akan efektif dan efisien.

Faktor sikap yang akan digali dalam penelitian ini adalah sikap pelaksanan kebijakan pada pelaksanaan pelayanan Perusahaan Daerah Air Minum Unit Boliyohuto Kabupaten Gorontalo. Sesuai dengan penelitian mengenai disposisi (sikap) yang menjadi indikator disposisi ini adalah sikap profisionalisme dan tangunggjawab dalam pemberian pelayanan Perusahaan Daerah Air Minum Unit Boliyohuto Kabupaten Gorontalo kepada masyrakat (pelangan) .

PDAM Unit Boliyohuto Kabupaten Gorontalo yang menunjukan bahwa pemberian layanan sudah cukupmengenai sikap profesional dan tanggung jawab dalam menyelesaikan tugasnya. Para pemberi layanan sudah memberikan tanggung jawab dalam kinerja pelayanan pada masyarakat terhadap pelayanan yang dihasilkan. Hal itu terlihat dalam kinerja petugas dalam memberikan selalu sesuai dengan peraturan dan prosedur sehingga menghasilkan produk pelayanan yang memuaskan bagi masyarakat (pelanggan). Seperti halnya dalam pembuatan daftar pelanggan dan rekening pembayaran sebelum diproses petugas memeriksa 
dengan penuh tanggung jawab kelengkapannya. Hal itu dilakukan agar tidak terjadi kesalahan dalam data. Walaupun terkadang ada sedikit kesalahan, tetapi pemberi layanan akan bertanggung jawab segera mungkin memperbaiki kesalahan tersebut dan memberikan yang terbaik untuk masyarakat (pelanggan).

\section{Struktur Birokrasi}

Struktur birokrasi adalah karakteristik, norma-norma, dan pola-pola hubungan yang terjadi berulang-ulang dalam badan-badan eksekutif yang mempunyai hubungan baik potensial maupun nyata dengan apa yang mereka miliki dalam menjalankan kebijakan. Menurut Edward III dalam penelitian (Subekti, Faozanudin, \& Rokhman, 2017), variabel keempat yang mempengaruhi implementasi kebijakan publik adalah struktur birokrasi. Walaupun sumber-sumber untuk melaksanakan suatu kebijakan tersedia atau para pelaksana kebijakan mengetahui apa yang seharusnya dilakukan dan mempunyai keinginan untuk melaksanakan suatu kebijakan, kemungkinan kebijakan tersebut tidak dapat terlaksana atau terealisasi karena terdapatnya kelemahan dalam struktur birokrasi.

Kebijakan yang begitu kompleks menuntut adanya kerjasama banyak orang, ketika struktur birokrasi tidak kondusif pada kebijakan yang tersedia, maka hal ini akan membuat sumberdayasumberdaya menjadi tidak efektif dan menghambat jalannya kebijakan. Birokrasi sebagai pelaksana sebuah kebijakan harus dapat mendukung kebijakan yang telah diputuskan dengan jalan melakukan koordinasi dengan baik.Dalam penelitian ini struktur yang dimaksud adalah standar operatioanal Procedur di dalam pelaksanaan kebijakan pelayanan Perusahaan Daerah Air Minum Unit Boliyohuto Kabupaten Gorontalo.

Diketahui bahwa prosedur yang dibutuhkan dalam pelaksanaan kebijakan Pelayanan PDAM Unit Boliyohuto Kabupaten Gorontalo diatur dalam bentuk tatacara baku pelaksanaan, yang lebih dikenal dengan SOP, SOP inilah yang menjadi acuan untuk seluruh pelaksana kebijakan pelayanan dalam hal ini para petugas PDAM sudah baik sesuai dengan Standar Oprasional Prosedur. Hanya saja dalam pemasangan sambungan baru kecepatannya agak lambat dan masih sangat tergantung dari lokasi tempat pemasangan, dan keadaan letak rumah pelangan, sehingga menghambat proses pelayanan sambungan baru, ada atau tidak adanya jaringan pipa, negosiasi dengan petugas, dan aturan prosedur tetap yang harus dijalankan yang pada akhirnya juga mempengaruhi dalam kecepatan sambungan baru.

Faktor-Faktor Pendukung Dan Penghambat Implementasi Pelayanan Perusahaan Daerah Air Minum (PDAM) Unit Boliyohuto Kabupaten Gorontalo 
Berdasarkan hasil penelitian yang dilakukan, dapat didefinisikan bahwa adanya hal-hal yang penghambat dan pendukung sehingga mempengaruhi implementasi kebijakan pelayanan Perusahaan Derah Air Minum (PDAM) Unit Boliyohuto Kabupaten Gorontalo.

1. Faktor pendukung dalam implementasi pelayanan perusahaan daerah air minum (PDAM) unit Boliyohuto Kabupaten Gorontalo adalah (1) Sumber air masih melebihi kapasitas sehingga air masih memungkinkan untuk jumlah pelanggan baru; (2) Dalam suatu pekerjaan kita langsung terjun ke lapangan demi kelancaran pelayanan; (3) Kekompakan staf yang ada menjadikan kekuatan dalam menyelesaikan permasalahan mengenai pelayanan.

2. Faktor penghambat dalam implementasi pelayanan Perusahaan Daerah Air Minum (PDAM) Unit Boliyohuto Kabupaten Gorontalo adalah Kurangnya birokrasi. Hal ini disebabkan karna pegawai yang bekerja dalam memberikan pelayanan hanya sedikit sehingga dalam pekerjaannya pegawai harus bekerja lebih dari satu pekerjaan, sehingga dapat memperlambat pelayanan adalah Kurangnya fasilitas pelayanan sehingga dapat menghambat pelayanan dimana fasilitas yang ada pada PDAM Unit Boliyohuto sangat minim, serta fator alam seperti banjir dan sebagainya yang yang bisa menghambat pendistribusian air dikarenakan aliran air dari sungai yang bercampur lumpur, membuat pipa rusak dan menjadikan kabur dan kotor air yang distribusikan kepada pelangan. Sehingga perlu penambahan sumur bor untuk mengantisipasi faktor alam karena sumur bor dianggap sedikit terkendala dan bisa mengantisipasi apabila terjadi kekaburan air diakibatkan faktor alam seperti banjir dan sebagainya

\section{PENUTUP}

\section{SIMPULAN}

Berdasarkan pembahasan mengenai analisis implementasi pelayanan masalah yang terdapat di lapangan maka dapat disimpulkan:

1. Secara garis besar beberapa indikator mengenai model implementasi pelayanan komunikasi, sudah berjalan dengan baik sosialisasi sering dilakukan dan memanfaatkan saluran komunikasi dengan baik, namun sumber daya yang belum sesuai harapan karena masalah sumber daya manusia dimana jumlah birokrasi yang melayani sedikit sehingga pegawai bekerja lebih dari satu pekerjaan dan minim sumber daya peralatan (fasilitas), kemudian untuk indikator disposisi yaitu sikap profesonal dan tangung jawab dalam pekerjaan sudah sesuai yang diharapkan, selanjutnya indikator struktur birokrasi sudah tersedia alur SOP dalam memberikan pelayanan 
sehingga jelas dan dapat dimengerti oleh semua pihak sebagai hasil dari indikator struktur birokrasi

2. Faktor-faktor pendukung dan penghambat dalam implementasi pelayanan PDAM Unit Boliyohuto Kabupaten Gorontalo adalah:

a. Faktor pendukung implementasi pelayanan PDAM Unit Boliyohuto Kabupaten Gorontalo antara lain: Sumber air masih melebihi kapasitas sehingga air masih memungkinkan untuk jumlah pelanggan baru. Dalam suatu pekerjaan kita langsung terjun ke lapangan demi kelancaran pelayanan, kekompakan staf yang ada menjadikan kekuatan dalam menyelesaikan permasalahan mengenai pelayanan.

b. Faktor penghambat implementasi pelayanan air minum bagi masyarakat pada PDAM Unit Boliyohuto Kabupaten Gorontalo antara lain : kurangnya sumber daya manusia, hal ini disebabkan karena pegawai yang bekerja dalam memberikan pelayanan hanya sedikit sehingga dalam pekerjaannya pegawai harus bekerja lebih dari satu pekerjaan, sehingga dapat memperlambat pelayanan, serta kurangnya sumber daya peralatan (fasilitas) pelayanan sehingga dapat menghambat pelayanan dimana fasilitas yang ada pada PDAM Unit Boliyohuto sangat minim.

\section{SARAN}

Berdasarkan hasil penelitian tersebut, penulis memberikan saran yang diharapkan dapat menjadi masukan bagi PDAM Unit Boliyohuto Kabupaten Gorontalo saran tersebut antara lain:

1. Untuk menghasilkan kualitas pelayanan yang lebih baik, perlu adanya penambahan jumlah pegawai ataupun melengkapi fasilitas yang ada sehingga dapat memberikan pelayanan yang berkualitas dan prima bagi pelanggan PDAM

2. Perlunya penambahan sumur bor guna mengantisipasi air yang keruh ke pelanggan saat terjadi meluapnya sungai dikarenakan faktor alam seperti banjir sehingga apabila mempunyai sumur bor dapat didistribusikan dahulu ketika terjadi banjir dan adanya kerusakan pipa di Tamaila sehingga sumur bor merupakan cadangan pendistibusian air disaat kerusakan pipa di Tamaila sehingga kualitas air pun dapat terjaga dan mengurangi macetnya pendistribusian air bersih.

\section{DAFTAR PUSTAKA}

Arikunto, S. (2014). Metode penelitian kuantitatif, kualitatif, dan kombinasi (mixed methods). Bandung: Alfabeta.

Budiaman. (2018). Manajemen Pelayanan Publik. Andi Offset.

Effendi, S. (2014). Implementasi dan Evaluasi Kebijakan Publik. Yogyakarta: MAP UGM.

Hamid, A. (2015). Otonomi Daerah dan Kualitas Pelayanan Publik. Buletin Pengawasan.

Indah, T., \& Hariyanti, P. (2018). Implementasi Kebijakan 
Keterbukaan Informasi Publik pada Dinas Kominfo Kota Tasikmalaya. Jurnal Komunikasi. https://doi.org/10.20885/komunikasi. vol12.iss2.art3

Katili, A. Y., \& Tueno, N. S. (2020). Analisis Implementasi Kebijakan Pengaturan Pengoperasian Kendaraan Bentor sebagai Moda Transportasi di Gorontalo, 9(1), 4654.

Lembaga Administrasi Negara Republik Indonesia. (2018). Peraturan Lembaga Administrasi Negara Republik Indonesia Nomor 12 Tahun 2018 Tentang Pelatihan Dasar Calon Pegawai Negeri Sipil. Lembaga Administrasi Negara Republik Indonesia.

Moleong, L. J. (2018). Metodologi Penelitian Kualitatif, cet. XI. Bandung: PT Remaja Rosdakarya.

Mouw, E. (2013). Kualitas Pelayan Publik di Daerah. Jurnal UNIERA.

Mulawarman, K., \& Rosilawati, Y. (2014). Komunikasi Organisasi. Jurnal Ilmiah Komunikasi Makna. https://doi.org/10.30659/jikm.5.1.3141

Ramdhani, A. R. M. A. (2016). Konsep Umum Pelaksanaan Kebijakan Publik. Jurnal Publik.

Rezha, F. (2013). Analisis Pengaruh Kualitas Pelayanan Publik Terhadap Kepuasan Masyarakat (Studi Tentang Pelayanan Perekaman Kartu Tanda Penduduk Elektronik (EKTP) Di Kota Depok). Jurnal Administrasi Publik Mahasiswa Universitas Brawijaya.

Riyanto, A. (2018). Implikasi Kualitas Pelayanan Dalam Meningkatkan Kepuasan Pelanggan Pada PDAM
Cibadak Sukabumi. Ecodemica.

Sadhana, K. (2010). Etika Birokrasi Dalam Pelayanan Publik.

Subekti, M., Faozanudin, M., \& Rokhman, A. (2017). Pengaruh komunikasi, sumber daya, disposisi dan struktur birokrasi terhadap efektifitas implementasi program bantuan operasional sekolah pada satuan pendidikan Sekolah Dasar Negeri di Kecamatan Tambak. The Indonesian Journal of Public Administration (IJPA), 3(2), 58-71.

Sugiyono. (2014). Metode Penelitian Pendidikan Pendekatan Kuantitatif, Kualitatif, dan R\&D. Metode Penelitian Pendidikan Pendekatan Kuantitatif, Kualitatif Dan $R \& D$.

Widodo, J. (2001). Etika birokrasi dalam pelayanan publik. Malang: CV Citra.

Zahara, E. (2018). Peranan Komunikasi Organisasi Bagi Pimpinan Organisasi. Jurnal Warta. 